\section{Root Cell Volume in the Planter Flat Affects Watermelon Seedling Development and Fruit Yield}

\author{
Aimin Liu' ${ }^{1}$ and Joyce G. Latimer ${ }^{2}$ \\ Department of Horticulture, University of Georgia, Georgia Experiment \\ Station, Griffin, GA 30223-1797
}

Additional index words. Citrullus lanatus, rooting volume restriction, seedling growth, transplant production

\begin{abstract}
The growth of 'Mirage' and 'StarBrite' watermelon [Citrullus lanatus (Thunb.) Matsum. and Nakai] transplants were evaluated in TODD 125, 100A, 150, 175, and 200 flats with root cell volumes of $18,26,36,46$, and $80 \mathrm{~cm}^{3}$, respectively. The effects of rooting volume restriction (RVR) on the number of leaves developed, leaf expansion, and shoot and root dry weight gain increased with time measured at 5, 10, 15, or 20 days after seedling emergence (DAE) for 'Mirage' or 4, 8, 12, or 16 DAE for 'StarBrite'. Generally, the greatest effect of RVR occurred between 10 and 15 DAE for 'Mirage' and 8 and 12 DAE for 'StarBrite' for most measurements. Root : shoot dry weight ratios generally were similar among the cell volumes. In a 1993 field test with 'StarBrite' grown in the previously described flats, transplants from the TODD 125s produced the least growth and the poorest yield in terms of fruit per plant, total number of marketable fruit, and total yield. Transplants from TODD 200s produced a higher total yield than plants from other cell volumes.
\end{abstract}

Watermelon transplant production is important to establish field plantings of expensive hybrid cultivars and to improve the grower's ability to meet early market demands (Ivanoff et al., 1960). Transplanted watermelons have more early vine growth and higher fruit yields than direct-seeded watermelons (Hall, 1989). However, in the greenhouse, roots of container-grown transplants are generally confined. Plants grown in small cells are less expensive to produce than those in large cells because less greenhouse space is required (Weston and Zandstra, 1986). However, suppressed plant growth often occurs due to rooting volume restriction (RVR), resulting in less vigorous plants; therefore, using plants grown in small cells may reduce yields compared to plantings established from larger transplants (Hall, 1989).

In tomato (Lycopersicon esculentum Mill.), small cells ( 4.4 to $31 \mathrm{~cm}^{3}$ ) reduced transplant growth and early yield but not total yield (Weston and Zandstra, 1986). Seedling weight and early yield of pepper (Capsicum annuum L.) increased with increasing rooting volume (Latimer, 1988; Weston, 1988). Dry weight accumulation in leaves, stems, roots, and fruit of greenhouse-grown squash (Cucurbita pepo

\footnotetext{
Received for publication 1 July 1994. Accepted for publication 5 Nov. 1994. We acknowledge the assistance of D.S. NeSmith in this research. The cost of publishing this paper was defrayed in part by the payment of page charges. Under postal regulations, this paper therefore must be hereby marked advertisement solely to indicate this fact.

${ }^{1}$ Graduate Research Assistant. Current address: Dept. of Agronomy and Plant Genetics, Univ. of Minnesota, St. Paul, MN 55108.

${ }^{2}$ Associate Professor.
}

L.) was reduced by RVR (350- vs. 2000- vs. $7600-\mathrm{cm}^{3}$ containers), but root : shoot dry weight ratio, timing, duration of flowering, and flower sex were not significantly affected by RVR (NeSmith, 1993a). Plant dry weight of 'Charleston Gray' or 'Crimson Sweet' watermelon transplants grown in $40-\mathrm{cm}^{3}$ root cells were 3 times greater than that of plants grown in 19- $\mathrm{cm}^{3}$ root cells (Hall, 1989).

Because most studies on the effect of cell volume on shoot growth report only endpoint measurements (final transplant size), we measured the growth of watermelon seedlings over time to determine the development of root restriction stress during transplant production and recorded fruit yield in one test after transplanting seedlings to field plots.

\section{Materials and Methods}

Greenhouse tests. TODD (Speedling, Sun City, Fla.) planter flats 125, 100A, 150, 175, and 200 (Table 1) were filled with a peatlite medium (Redi-Earth, W.R. Grace \& Co., Cambridge, Mass.). In separate experiments, two commercially important hybrid watermelon cultivars, 'Mirage' (a cultivar commonly planted in Georgia) and 'StarBrite' (a new
${ }^{\mathrm{u}}$ Flats are listed in order of increasing cell volume. hybrid with disease resistance superior to 'Mirage') were seeded on 14 July and 15 Aug. 1991, respectively, in randomized completeblock designs. Beginning 7 days after seedling emergence (DAE), plants were watered daily and fertilized twice weekly with $200 \mathrm{ppm} \mathrm{N}$ of 20N-8.7P-16.6K (Grace Sierra, Milpitas, Calif.). Greenhouse temperatures averaged 27C day/22C night and photosynthetic photon flux averaged $9.0 \mathrm{~mol} \cdot \mathrm{m}^{-2} \cdot$ day $^{-1}$.

Six plants in each of the four replications per treatment were harvested for growth measurement at 5, 10, 15, and $20 \mathrm{DAE}$ for 'Mirage' and 4, 8, 12, and $16 \mathrm{DAE}$ for 'StarBrite' $(\mathrm{n}=24)$. Seedlings were cut just above the medium surface. Growth measurements included leaf count and area (model LI-3000; LI-COR, Lincoln, Neb.) and dry weights of leaf, stem, and root tissues (after washing the medium off by hand) that were obtained after samples were dried in a forced-air oven at $65 \mathrm{C}$ for $48 \mathrm{~h}$. Shoot dry weight and root : shoot dryweight ratios were calculated.

Transplant production and field test. On 22 Apr. 1993, 'StarBrite' watermelon seeds were sown in TODD planter flats $125,100 \mathrm{~A}$, 150,175 , or 200 and were grown as described previously in a randomized complete-block design with three replications (one flat of each size per replication). At $16 \mathrm{DAE}$, six uniform seedlings were collected from each flat per replication for transplant growth measurement $(n=18)$. Thirty of the remaining plants in each treatment $\times$ replication subplot were transplanted to a Cecil sandy clay loam (clayey, kaolinitic, thermic Typic Hapludult) field at the Dempsey Horticulture Farm, Griffin, Ga. The field design consisted of a randomized complete block of three replications of five plots with each cell volume treatment randomly arranged within each replication. Each plot was three rows wide with $1.5 \mathrm{~m}$ between rows; each row was $16 \mathrm{~m}$ long with $1.5 \mathrm{~m}$ between plants. 'Mirage' was planted on the edges of the experimental area in guard rows. Before transplanting, $560 \mathrm{~kg} \cdot \mathrm{ha}^{-1}$ of a $10 \mathrm{~N}-$ 4.4P-8.3K fertilizer (Akin Feed and Seed, Griffin, Ga.) was incorporated into the field, with an additional $78 \mathrm{~kg}$ N/ha broadcast 4 weeks after transplanting. Weeds were controlled by hand-weeding. Overhead-sprinkler irrigation supplemented rainfall to obtain 40 mm water/week. On 2 Aug. 1993, all watermelon fruit were harvested from all three rows in each plot. All fruit were picked and weighed individually to evaluate treatment effects on fruit development (NeSmith, 1993b). Fruit weighing $\geq 6.8 \mathrm{~kg}$ were considered marketable. Soluble solids concentration was mea-

Table 1. Physical characteristics of five TODD planter flats (Speedling, Sun City, Fla.).

\begin{tabular}{|c|c|c|c|c|c|c|}
\hline \multirow[b]{2}{*}{$\begin{array}{l}\text { TODD } \\
\text { flat }^{z}\end{array}$} & \multicolumn{5}{|c|}{ Cell } & \multirow[b]{2}{*}{$\begin{array}{r}\text { No./ } \\
\text { flat }\end{array}$} \\
\hline & $\begin{array}{c}\text { Side } \\
\text { length } \\
(\mathrm{cm})\end{array}$ & $\begin{array}{c}\text { Surface } \\
\text { area } \\
\left(\mathrm{cm}^{2}\right)\end{array}$ & $\begin{array}{c}\text { Depth } \\
(\mathrm{cm})\end{array}$ & $\begin{array}{c}\text { Surface } \\
\text { area : depth } \\
\text { ratio }\end{array}$ & $\begin{array}{l}\text { Vol. } \\
\left(\mathrm{cm}^{3}\right)\end{array}$ & \\
\hline 125 & 3.25 & 10.6 & 4.60 & 2.30 & 18 & 162 \\
\hline $100 \mathrm{~A}$ & 2.75 & 7.6 & 7.50 & 1.01 & 26 & 200 \\
\hline 150 & 3.80 & 14.4 & 6.25 & 2.31 & 36 & 128 \\
\hline 175 & 4.50 & 20.3 & 6.25 & 3.29 & 46 & 72 \\
\hline 200 & 5.20 & 27.0 & 7.35 & 3.68 & 80 & 72 \\
\hline
\end{tabular}


sured with a hand-refractometer (ATAGOCo., Tokyo) for a fruit subsample of each plot.

Statistical analysis. All experiments were conducted in a randomized complete-block design, with four replications for greenhouse tests and three for the field test. Data were subjected to the general linear models procedure of SAS (Littell et al., 1991). Regression analysis was used to model leaf count and area and root and shoot dry weights in response to increased rooting volumes at each of the four harvest dates. Differences between harvest dates were determined by paired $t$ tests of the slopes in the greenhouse tests. In 1993, trend analysis was used to examine yield measurements of transplants in the field test.

\section{Results and Discussion}

Greenhouse tests (plant growth vs. RVR). The number of expanding leaves and the leaf area of 'Mirage' seedlings harvested at 5, 10, 15 , and 20 DAE increased with increasing rooting volume $\left(18\right.$ to $\left.80 \mathrm{~cm}^{3}\right)$ (Fig. 1). The effect of RVR also increased as the plants grew, demonstrated by the increasing slopes of the regression lines for both growth measurements at successive harvest dates. The regression line slope for number of leaves vs. root cell volume at $10 \mathrm{DAE}$ was greater than that at $5 \mathrm{DAE}$, indicating that RVR had a greater effect on number of leaves at $10 \mathrm{DAE}$ than at 5 DAE (Fig. 1A). Nonsignificant differences in the slopes of the regression lines of leaf count vs. cell volume after 10 DAE suggest that RVR continued to affect leaf development to a similar extent over those periods. The slopes of the regression lines for leaf area vs. increasing rooting volume increased from 5 to $15 \mathrm{DAE}$ and then remained unchanged after $15 \mathrm{DAE}$, suggesting that leaf area had the same response to RVR at $15 \mathrm{DAE}$ as it did at 20 DAE (Fig. 1B).

Root and shoot dry weights of 'Mirage' plants also were affected by cell volume and seedling harvest date (Fig. 2). The slopes of the regression lines for root dry weight vs. increasing cell volume increased with harvest date, indicating that root dry weight gain was reduced more by RVR at each subsequent harvest date (Fig. 2A). Shoot dry weight exhibited a similar response to RVR over harvest dates (Fig. 2B). As plants grew, the increased differences in root and shoot dry weights between smaller and larger cell volumes reflected an increased RVR effect. Furthermore, leaf area and root and shoot dry weights of 'Mirage' showed similar patterns in response to increasing rooting volume during the experiment (i.e., the greatest response to RVR occurred between 10 and 15DAE, as indicated by a marked increase in the slopes of the regression lines between these two dates).

The similarity in root and shoot dry-weight responses to RVR during the experiment (Fig. 2) explains the notable consistency in the root : shoot dry weight ratios (data not presented). Although a linear trend was observed in root : shoot ratio of 'Mirage' seedlings vs. root cell volumes at 5 (ratio range 0.20 to 0.16 ), 10 (0.23 to 0.19$)$, and 15 (0.23 to 0.19) DAE, the

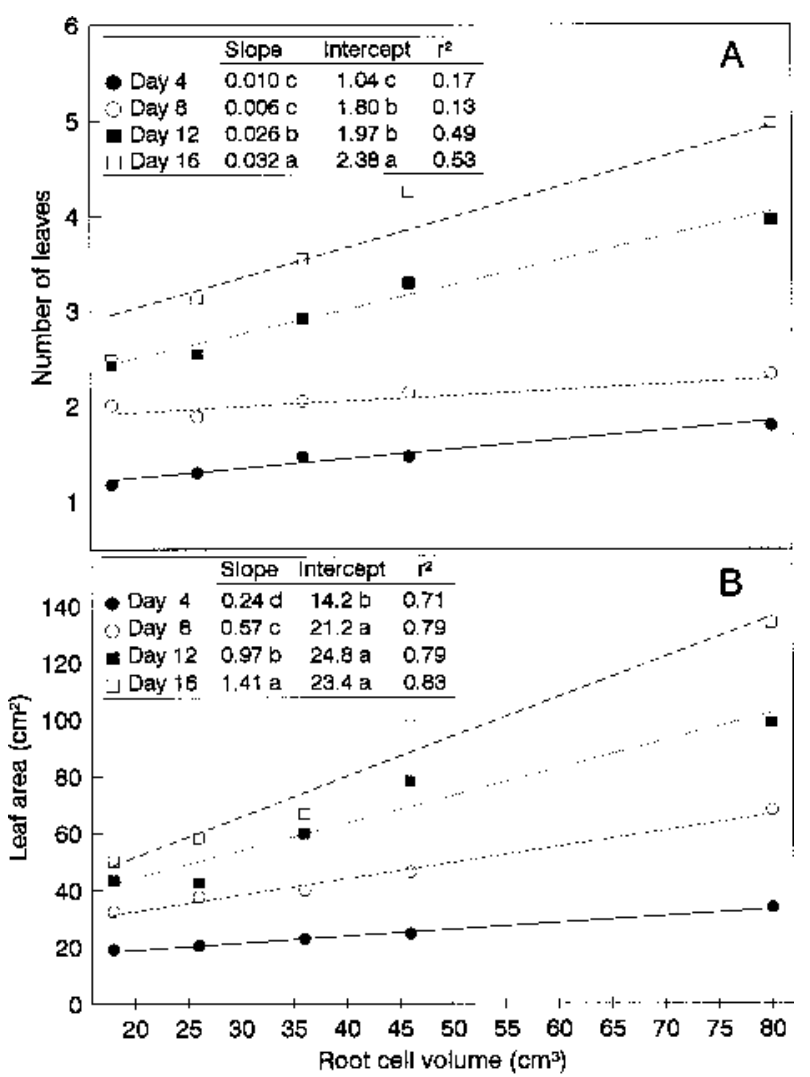

Fig. 1. Linear regressions of leaf (A) counts or (B) area of 'Mirage' watermelon over increasing cell volumes $\left(18\right.$ to $\left.80 \mathrm{~cm}^{3}\right)$. Tables within figures show regression characteristics; different letters indicate significant differences among regression coefficients for subsequent harvest dates determined by paired $t$ tests at $P \leq 0.05$.

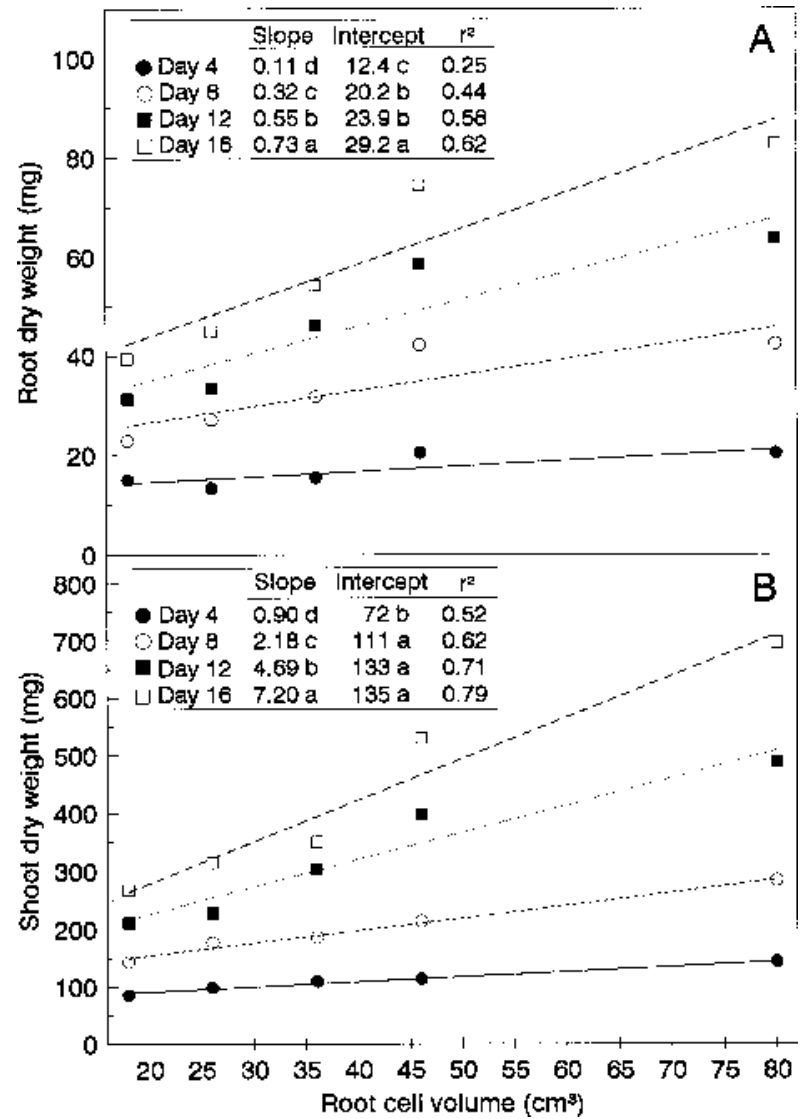

Fig. 2. Linear regressions of (A) root or (B) shoot dry weights of 'Mirage' watermelon over increasing cell volumes $\left(18\right.$ to $\left.80 \mathrm{~cm}^{3}\right)$. Tables within figures show regression characteristics, with different letters indicating significant differences among regression coefficients for subsequent harvest dates as determined by paired $t$ tests at $P \leq 0.05$. 
ratios were relatively constant over the cell volumes. The root : shoot ratio has responded inconsistently to limited cell volume; Ruff et al. (1987) reported an increase with tomato plants grown in 450 - vs. $13,500-\mathrm{cm}^{3}$ containers, and Peterson et al. (1991) reported a decrease in root : shoot ratio in tomato plants grown in $25-$ vs. $1500-\mathrm{cm}^{3}$ containers.

Due to the rapid growth rate of 'StarBrite' noted in preliminary experiments, plant growth in our greenhouse test was sampled at 4-day intervals. RVR showed an increasing effect on the 'StarBrite' growth measurements during the experiment, except for the number of leaves (Fig. 3A), which responded similarly to RVR at 4 and 8 DAE. Leaf area was reduced more by RVR as plants developed over time, as indicated by the increased slopes of the regression lines for these growth measurements vs. increasing rooting volume at each subsequent harvest date (Fig. 3B).

Root and shoot dry weights of 'StarBrite' seedlings responded to RVR in a manner similar to leaf area (Fig. 4 A and B). As with 'Mirage', root : shoot ratios for 'StarBrite' were similar over the cell volume range. Although trend analysis of root : shoot ratios of 'StarBrite' showed some significance, the responses were not clearly related to cell volume, and differences were small. The ratios ranged from 0.14 to 0.19 at $4 \mathrm{DAE}$; from 0.15 to 0.20 at $8 \mathrm{DAE}$; from 0.13 to 0.16 at $12 \mathrm{DAE}$; and from 0.12 to 0.16 at 16 DAE. However, the general lack of response of root : shoot dry weight ratio to cell volume is consistent with NeSmith's (1993a) results.

Transplant growth and watermelon yield. Because our yield results are only for 1993, they may be considered preliminary. Before planting, growth measurements of 'StarBrite' transplants showed the same linear responses to increasing cell volume as described in the 1991 greenhouse tests (data not presented). The total number of fruit per plant, the total number of marketable fruit $(\geq 6.8 \mathrm{~kg})$, and the total fruit yield increased with increasing rooting volume (19 to $80 \mathrm{~cm}^{3}$; TODD 125 to 200 ) (Table 2). There was significantly more fruit per plant and marketable fruit from plants grown in $80-\mathrm{cm}^{3}$ flats (TODD 200) than from those grown in $18-\mathrm{cm}^{3}$ flats (TODD 125 ; singledegree-of-freedom contrast, $P \leq 0.05$ ). Transplants grown in TODD 200s produced a significantly higher total fruit yield than plants grown in the other cell volumes (contrast analysis; TODD 200 vs. all other TODD flats; $P \leq$ $0.05)$.

Hall (1989) reported that 'Charleston Gray' watermelon plants grown in $40-\mathrm{cm}^{3}$ cells produced higher late and total yields than those grown in $19-\mathrm{cm}^{3}$ cells, but 'Crimson Sweet' yield was not affected by cell size, suggesting that yield response to cell size may vary among cultivars. However, Vavrina et al. (1993) reported that although cell volume $(19,31$, or 61 $\mathrm{cm}^{3}$ ) affected plant size (no data presented), it did not influence total fruit yield of 'Charleston Gray'. Plant establishment may be affected by planting or environmental conditions, but tomato plants with larger root systems seemed to suffer less transplant stress than plants grown in smaller cell volumes (Weston and Zandstra, 1986). Differences in long-term response to rooting volume may relate to plant establishment, cultivar vigor, or the length of time the plants were held in the flat (i.e., the degree of RVR to which the plants were exposed).

Although yield responses of 'StarBrite' to rooting volume were significant, the effect of cell volume on fruit weight distribution at each weight class was not significant (data not presented). These results indicate that the root cell volumes used for transplant production in this experiment did not affect the pattern of subsequent fruit development. Vavrina et al. (1993) concluded that watermelon transplants differing in size due to plant age at the time of planting seemed able to physiologically synchronize fruit set and development. Perhaps differences in transplant size due to RVR are ameliorated in a similar manner. Neither plant spacing in the field nor experimental year affected cumulative fruit weight distributions of 'StarBrite' (NeSmith, 1993b), again suggesting fruit set and development synchronization. The mechanism of this synchronization should be explored further.

Planter flats chosen in these studies had cells that varied not only in volume but also in side length, surface area, and depth (Table 1). All these factors may affect plant growth. Transplants from TODD 125s not only had the least shoot growth in the study but also were the least productive in the field in terms of

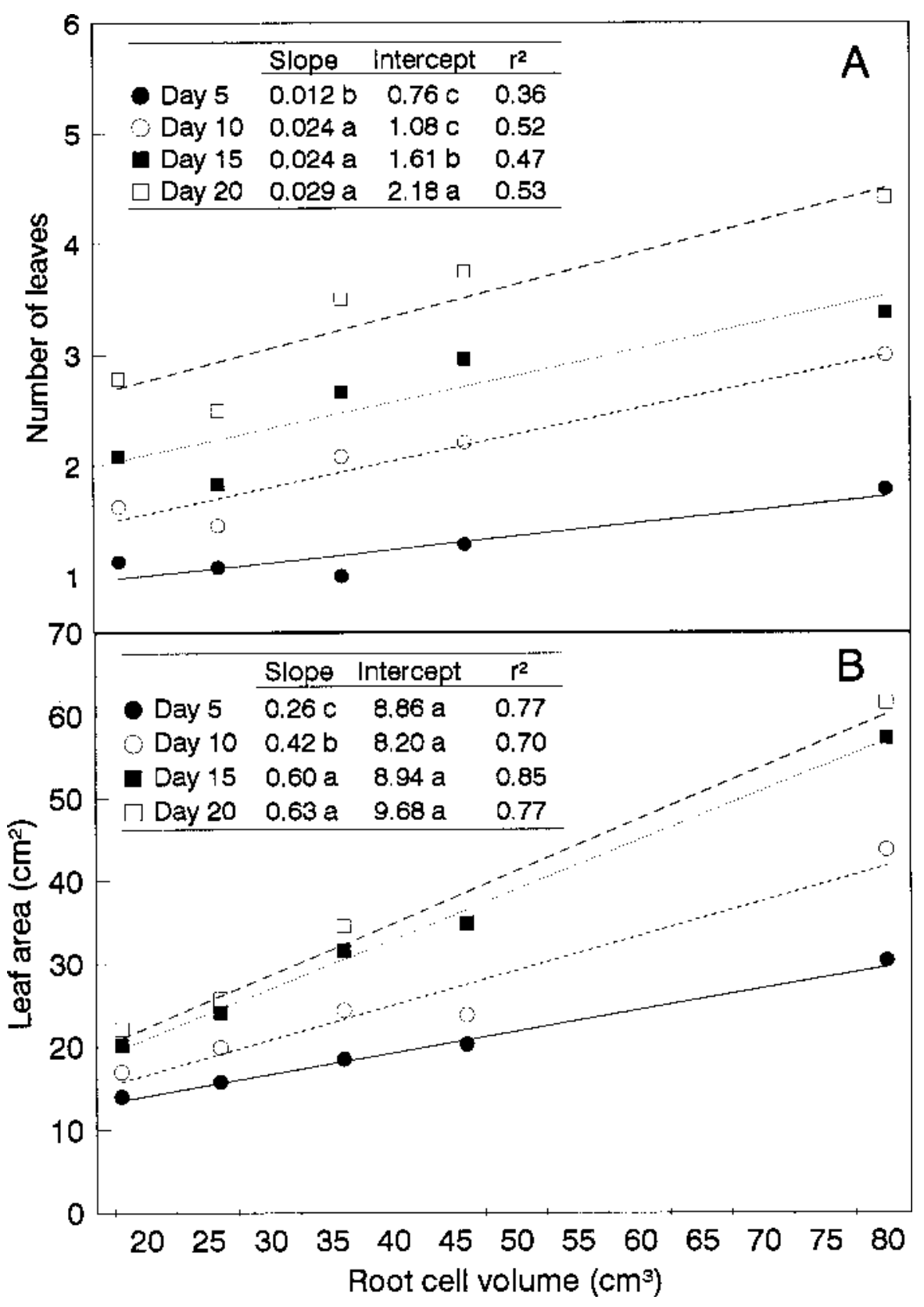

Fig. 3. Linear regressions of leaf (A) count and (B) area of 'StarBrite' watermelon over increasing cell volumes $\left(18\right.$ to $\left.80 \mathrm{~cm}^{3}\right)$. Tables within figures show regression characteristics, with different letters indicating significant differences among regression coefficients for subsequent harvest dates as determined by paired $t$ tests at $P \leq 0.05$. 
number of fruit per plant, marketable fruit, and total fruit yield, probably due to those flats having the smallest cell depth and volume.

Because we believe that the influence of water availability and nutrition have been minimized by regular frequent irrigation and fertilization, the suppression of plant growth under these RVR conditions probably relates to the physiological status of the watermelon plants. Younger (3 weeks old) tomato transplants had higher chlorophyll contents, specific leaf areas, and relative growth rates than older ( $\leq 6$ weeks old) transplants (Leskovar et al., 1991). These responses may be age related or due to RVR, because, for watermelon, time in the planter flat corresponds to increasing RVR effects (Figs. 1-4). Leaves of cucumber (Cucumis sativus L.) plants grown for 7 weeks in 400-, 1300-, 2900-, or 5900- $\mathrm{cm}^{3}$ containers had lower rates of carbon metabolism and photosynthesis with increasing root restriction (Robbins and Pharr, 1988). However, reductions in photosynthetic rates of cotton (Gossypium hirsutum L.) are reversible once the root restriction is alleviated (Thomas and Strain, 1991). These photosynthetic responses may be direct results of feedback inhibition due to starch accumulation (Thomas and Strain, 1991) or indirect responses due to altered synthesis and transport of root-produced plant hormones (Carmi et al., 1983). Preliminary data suggest that abscisic acid levels in roots and xylem exudate of 'StarBrite' watermelon plants grown in $18-$ or $26-\mathrm{cm}^{3}$ cells (TODD $125 \mathrm{~s}$ or $100 \mathrm{As}$ ) are consistently higher than those of larger cell volumes (unpublished data).

Although the mechanism by which RVR reduces shoot growth of plants is still unknown, the effect on transplant growth is well established for a variety of crops. Differences in watermelon shoot growth are significant at only 4 or 5 DAE. Long-term effects on plant performance and yield seemed to vary by cultivar (Hall, 1989). Perhaps to minimize cell volume effects on shoot growth, we should recommend that growers remove transplants from the flats as soon as the they have attained the necessary balance between root mass and soil volume for the removal of undamaged roots during plant pulling, as described by Vavrina and Orzolek (1993) for tomato. Because watermelon transplants are more sensitive to root disturbance than crops such as tomato, the plants should not be pulled from the flat before the root ball can be removed intact. Researchers also should be cognizant of the speed with which container volume affects shoot growth.

\section{Literature Cited}

Carmi, A., J.D. Hesketh, W.T. Enos, and D.B. Peters. 1983. Interrelationships between shoot growth and photosynthesis as affected by root growth restriction. Photosynthetica 17:240-245.

Hall, M.R. 1989. Cell size of seedling containers influences early vine growth and yield of transplanted watermelon. HortScience 24:771-773.

Ivanoff, S.S., R.C. Albritton, C.L. Blount, and B.E. Waggoner. 1960. Watermelon transplants for healthier, earlier and more profit-

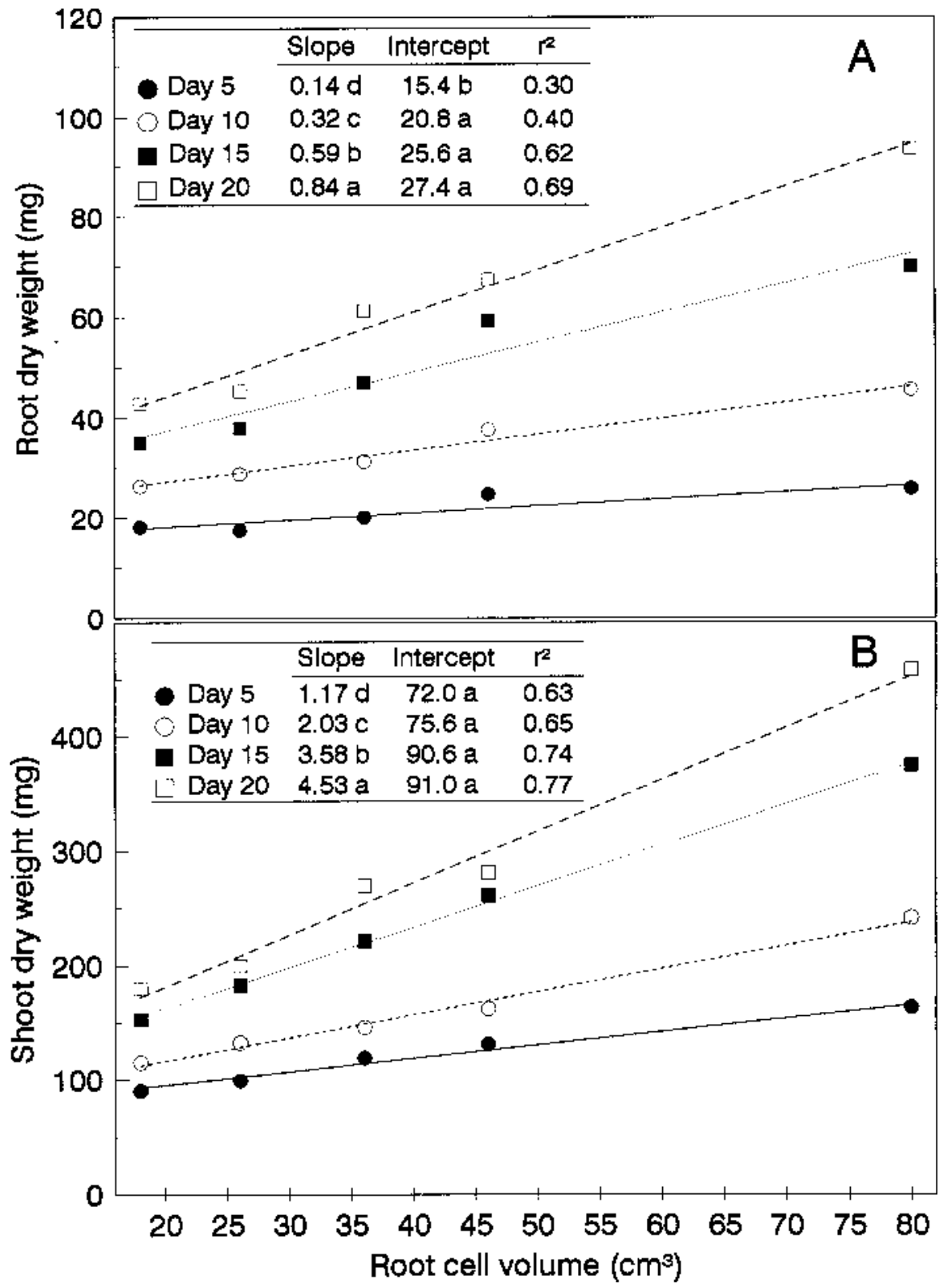

Fig. 4. Linear regressions of (A) root and (B) shoot dry weights of 'StarBrite' watermelon over increasing cell volumes $\left(18\right.$ to $\left.80 \mathrm{~cm}^{3}\right)$. Tables within figures show regression characteristics, with different letters indicating significant differences among regression coefficients for subsequent harvest dates as determined by paired $t$ tests at $P \leq 0.05$.

Table 2. Fruit yield and soluble solids concentration of 'StarBrite' watermelon as affected by different root cell volumes during transplant production (Summer 1993).

\begin{tabular}{|c|c|c|c|c|c|}
\hline $\begin{array}{l}\text { TODD } \\
\text { flat }\end{array}$ & $\begin{array}{l}\text { No. } \\
\text { fruit/ } \\
\text { plant }\end{array}$ & $\begin{array}{c}\text { Marketable } \\
\text { fruit }^{\mathrm{z}} \\
(\text { no./ha } \times 1000)\end{array}$ & $\begin{array}{c}\text { Avg } \\
\text { fruit wt } \\
\text { (kg/fruit) }\end{array}$ & $\begin{array}{c}\text { Soluble } \\
\text { solids } \\
(\%)\end{array}$ & $\begin{array}{c}\text { Total } \\
\text { yield } \\
\left(\mathrm{t} \cdot \mathrm{ha}^{-1}\right)\end{array}$ \\
\hline$\overline{125}$ & 2.4 & 6.0 & 7.4 & 11.4 & 76.4 \\
\hline $100 \mathrm{~A}$ & 2.8 & 6.8 & 7.4 & 11.1 & 88.4 \\
\hline 150 & 2.9 & 6.9 & 7.6 & 10.9 & 92.0 \\
\hline 175 & 2.9 & 7.1 & 7.5 & 11.3 & 92.3 \\
\hline 200 & 3.2 & 8.7 & 8.4 & 11.4 & 115.6 \\
\hline \multicolumn{6}{|l|}{ Contrasts } \\
\hline Linear & $* *$ & $*$ & NS & NS & $* *$ \\
\hline Quadratic & NS & NS & NS & NS & NS \\
\hline
\end{tabular}

${ }^{\mathrm{z}}$ Marketable fruit $\geq 6.8 \mathrm{~kg}$.

ss, *** Nonsignificant or significant (linear or quadratic contrast analysis) at $P \leq 0.05$ or 0.01 , respectively.

able crops. Mississippi Agr. Expt. Sta. Bul. 588.

Latimer, J.G. 1988. Effect of planter flat and root cell size on growth and field establishment of bell pepper transplants. HortScience 23:813. (Abstr.)
Leskovar, D.I., D.J. Cantliffe, and P.J. Stoffella. 1991. Growth and yield of tomato plants in response to age of transplants. J. Amer. Soc. Hort. Sci. 116:416-420.

Littell, R.C., F.J. Freund, and P.C. Spector. 1991. 
SAS system for linear models. SAS Institute, Cary, N.C.

NeSmith, D.S. 1993a. Influence of root restriction on two cultivars of summer squash (Cucurbita pepo L.). J. Plant Nutr. 16(3):421-431.

NeSmith, D.S. 1993b. Plant spacing influences watermelon yield and yield components. HortScience 28:885-887.

Peterson, T.A., M.D. Reinsel, and D.T. Krizek. 1991. Tomato (Lycopersicon esculentum Mill. cv. 'Better Bush') plant response to root restriction. J. Expt. Bot. 42(243):1233-1240.
Robbins, N.S. and D.M. Pharr. 1988. Effect of restricted root growth on carbohydrate metabolism and whole plant growth of Cucumis sativus L. Plant Physiol. 87:409-413.

Ruff, M.S., D.T. Krizek, R.M. Mirecki, and D.W. Inouye. 1987. Restricted root zone volume: Influence on growth and development of tomato. J. Amer. Soc. Hort. Sci. 112:763-769.

Thomas, R.B. and B.R. Strain. Root restriction as a factor in photosynthetic acclimation of cotton seedlings grown in elevated carbon dioxide. Plant Physiol. 96:627-634.
Vavrina, C.S., S. Olson, and J.A. Cornell. 1993. Watermelon transplant age: Influence on fruit yield. HortScience 28:789-790.

Vavrina, C.S. and M.D. Orzolek. 1993. Tomato transplant age: A review. HortTechnology 3:313-316.

Weston, L.A. 1988. Effect of flat cell size, transplant age, and production site on growth and yield of pepper transplants. HortScience 23:709-711.

Weston, L.A. and B.H. Zandstra. 1986. Effect of root container size and location of production on growth and yield of tomato transplants. J. Amer. Soc. Hort. Sci. 111:498-501. 